\title{
Analisis Kepatuhan Wajib Pajak Orang Pribadi Terhadap Penerimaan Pajak Di Kantor Pelayanan Pajak Pratama Palembang Ilir Timur
}

\author{
Oktariansyah 1 , Mohammad Aryo Arifin², Hilma Yunia ${ }^{3}$ \\ ${ }^{1}$ Fakultas Ekonomi dan Bisnis, Universitas PGRI Palembang, rianbro82@univpgri-palembang.ac.id \\ ${ }^{2}$ Fakultas Ekonomi dan Bisnis, Universitas PGRI Palembang,aryoarifin@univpgri-palembang.ac.id \\ ${ }^{3}$ Fakultas Ekonomi dan Bisnis, Universitas PGRI Palembang
}

\begin{abstract}
ABSTRAK
Penelitian ini bertujuan untuk mengetahui bagaimana kepatuhan Wajib Pajak Orang Pribadi Terhadap Penerimaan Pajak di Kantor Pelayanan Pajak Pratama Palembang llir Timur. Metode yang digunakan dalam penelitian ini adalah metode kuantitatif dimana jenis data yang digunakan dalam penelitian ini berupa angka-angka dan dianalisa berdasarkan jumlah SPT tahunan orang pribadi yang menyampaikan dan jumlah penerimaan pajak orang pribadi yang terdaftar pada KPP Pratama Palembang llir Timur, sedangkan sumber data yang digunakan adalah sumber data sekunder dan teknik pengumpulan data yang digunakan adalah dokumentasi yaitu berupa data jumlah wajib pajak orang pribadi yang terdaftar tahun 2014-2018, jumlah SPT orang pribadi yang melaporkan tahun 2014-2018, realisasi penerimaan pajak tahun 2014-2018, target penerimaan pajak tahun 2014-2018. Hasil penelitian menunjukkan bahwa tingkat kepatuhan Wajib Pajak orang pribadi pada KPP Pratama Palembang llir Timur masih kurang bila dilihat dari tingkat kepatuhan wajib pajak orang pribadi dalam menyampaikan SPT, pada tahun 2014 sampai dengan 2015 kurang patuh yaitu dengan persentase $61,41 \%$ - 69,63\%, pada tahun 2016 sampai dengan 2017, cukup patuh yaitu dengan persentase $89,54 \%, 84,96 \%$, pada tahun 2018 kepatuhan wajib orang pribadi kembali kurang patuh karena hanya mencapai $72,03 \%$. Sedangkan berdasarkan penerimaan pajak orang pribadi dapat disimpulkan bahwa KPP Pratama Palembang llir Timur belum bisa memenuhi atau mencapai target yang telah ditentukan hal ini dapat dilihat dari hasil persentase penerimaan pajak orang pribadi dari tahun 20142018 hanya tahun 2015 yang mencapai target yang telah ditentukan yaitu $257,65 \%$. Hal ini terjadi karena kurangnya kesadaran dan inisiatif wajib pajak orang pribadi dalam menyampaikan SPT Tahunan dan pentingnya membayar pajak untuk pembangunan negara.
\end{abstract}

Kata kunci: Kepatuhan Wajib Pajak, Wajib Pajak Orang Pribadi, Penerimaan Pajak.

\section{ABSTRACT}

This study aims to determine how the compliance of individual taxpayers with tax receipts at the Pratama Palembang Ilir Timur Tax Service Office. The method used in this study is a quantitative method where the type of data used in this study is in the form of numbers and analyzed based on the number of individual annual tax returns that submit and the amount of individual tax receipts registered at the KPP Pratama Palembang llir Timur, while the data sources used used is a secondary data source and the data collection technique used is documentation in the form of data on the number of registered individual taxpayers in 2014-2018, the number of individual tax returns that report 20142018, the realization of tax revenues for 2014-2018, the target of tax revenue 2014-2018 years. The results show that the level of compliance of individual taxpayers at KPP Pratama Palembang llir Timur is still lacking when viewed from the level of compliance of individual taxpayers in submitting SPT, in 2014 to 2015 it was less compliant with the percentage of $61.41 \%-69.63 \%$, in 2016 to 2017, quite obedient, namely with a percentage of $89.54 \%, 84.96 \%$, in 2018 the mandatory compliance of individuals was again less obedient because it only reached $72.03 \%$. Meanwhile, based on individual tax receipts, it can be concluded that the KPP Pratama Palembang llir Timur has not been able to meet or achieve the predetermined target, this can be seen from the results of the percentage of individual tax revenues from 2014-2018 only 2015 which reached the predetermined target of 257 ,65\%. This happens because of the lack of awareness and initiative of individual taxpayers in submitting the Annual SPT and the importance of paying taxes for the development of the country.

Keywords: Taxpayer Compliance, Individual Taxpayers, Tax Revenue. 


\section{A. PENDAHULUAN}

Pengeluaran Negara Indonesia setiap tahunnya sangat banyak dan membutuhkan dana yang sangat besar untuk menutupi pengeluaran tersebut. Pengeluaran tersebut digunakan untuk berbagai hal, antara lain pembangunan infrasruktur untuk kepentingan umum, belanja pegawai, belanja barang, pembayaran bunga utang, subsidi, bantuan sosial, dan belanja lain-lain. Di sisi lain, pemerintah juga membutuhkan penerimaan untuk menutupi seluruh pengeluaran negara setiap tahunnya.

Salah satu sumber penerimaan yang paling potensial ialah dari penerimaan pajak. Penerimaan pajak dapat berasal dari Pajak Penghasilan (PPh), Pajak Pertambahan Nilai (PPN), Pajak Atas Penjualan Barang Mewah (PPNBM), dan Bea Materai maupun pajak lainnya. Untuk meningkatkan penerimaan pajak, usaha yang dilakukan pemerintah antara lain dengan ekstenfikasi dan intensifikasi penerimaan pajak. Ekstenfikasi ditempuh dengan meningkatkan jumlah wajib pajak yang aktif, sedangkan intensifikasi dapat ditempuh melalui meningkatkan kepatuhan wajib pajak.

Wajib pajak dikatakan patuh apabila wajib pajak tersebut dapat memenuhi dan melaksanakan kewajiban pajak. Kewajiban perpajakan harus dilaksanakan karena merupakan suatu tanggung jawab yang harus di penuhi oleh semua wajib pajak. Kepatuhan wajib pajak mempunyai hubungan dengan penerimaan pajak karena apabila kepatuhan wajib pajak mengalami peningkatan maka secara tidak langsung juga akan memperbesar penerimaan Negara dari sektor pajak. Di suatu KPP sering sekali ditemukan permasalahan ketidak patuhan wajib pajak dan masih banyak pula wajib pajak orang pribadi yang tidak patuh atau terlambat dalam mendaftarkan SPT. Ini semua dapat mengakibatkan berkurangnya penyetoran dana pajak ke kas negara dan menghambat kinerja pajak yang dapat mempengaruhi realisasi penerimaan pajak yang sangatlah penting.

\section{B. KAJIAN TEORI}

\section{Pengertian Pajak}

Menurut Undang-undang Ketentuan Umum Perpajakan Nomor 16 Tahun 2009 menyatakan bahwa dalam pasal 1 (satu), pajak merupakan kontribusi wajib pajak kepada negara yang terutang oleh orang pribadi atau badan yang bersifat memaksa berdasarkan undang-undang, dengan tidak mendapatkan imbalan secara langsung dan digunakan untuk keperluan negara bagi sebesar-besarnya kemakmuran rakyat.

Terdapat beberapa definisi pajak yang dikemukakan oleh para ahli, yaitu:

a. Menurut Prof. Dr. P.J.A. Adriani (Diana, 2013:34) pajak adalah iuran masyarakat kepada negara (yang dapat dipaksakan) yang terutang oleh yang wajib membayarnya menurut peraturan- peraturan umum (undang-undang) dengan tidak mendapat prestasi kembali yang langsung dapat ditunjuk dan yang gunanya adalah untuk membiayai pengeluaran-pengeluaran. Umum berhubung tugas negara untuk menyelenggarakan pemerintahan.

b. Menurut Prof. Dr. Djajadiningrat (Diana, 2013:34) Pajak adalah suatu kewajiban untuk menyerahkan sebagian kekayaan Negara karena suatu keadaan, kejadian, dan perbuatan yang memberikan kedudukan tertentu. Pungutan tersebut bukan sebagai hukuman, tetapi menurut peraturan-peraturan yang ditetapkan pemerintah serta dapat dipaksakan. Untuk itu, tidak ada jasa balik dari Negara secara langsung, misalnya untuk memelihara kesejahteraan 
umum.

c. Menurut pasal 1 Undang-Undang No.28 Tahun 2007 tentang ketentuan Umum dan Tatacara Perpajakan (Diana,2013:36, Abdul Halim, Icuk Rangga Bawono, Amin Dara, 2014:15) Pajak adalah kontribusi wajib kepada negara yang terutang oleh orang pribadi atau badan yang bersifat memaksa berdasarkan Undang-Undang, dengan tidak mendapat kontraprestasi secara langsung dan digunakan untuk keperluan negara bagi sebesar-besarnya kemakmuran rakyat.

Dari definisi tersebut, dapat diuraikan beberapa unsur pajak antara lain:

1. Pajak merupakan iuran dari rakyat kepada negara.

2. Pajak dipungut berdasarkan Undang-Undang

3. Tidak ada kontraprestasi secara langsung oleh pemerintah dalam pembayaran pajak

4. Digunakan untuk membiayai pengeluaran pajak.

\section{Fungsi Pajak}

Menurut Diana (2013:37) ada dua macam fungsi pajak yaitu sebagai berikut:

a. Fungsi Penerimaan (budgeter)

Sebagai alat (sumber) untuk memasukkan uang sebanyak-banyaknya dalam Kas Negara dengan tujuan untuk membiayai pengeluaran negara yaitu pengeluaran rutin dan pembangunan.

b. Fungsi Mengatur (regular)

Sebagai alat untuk mencapai tujuan tertentu di bidang keuangan (umpamanya bidang ekonomi, politik, budaya, pertahanan keamanan).

\section{Penggolongan Pajak}

Menurut Diana (2013:43) pajak dapat di kelompokkan ke dalam golongan sebagai berikut:

a. Menurut Sifatnya

1) Pajak Subyektif, yaitu pajak yang erat kaitannya atau hubungannya dengan subyek pajak atau yang dikenakan pajak dan besarnya dipengaruhi oleh keadaan wajib pajak.

2) Pajak objektif, yaitu pajak yang erat hubungannya dengan obyek pajak, yang selain dari pada benda dapat pula berupa keadaan, perbuatan atau peristiwa yan menyebabkan timbulnya kewajiban membayar.

b. Menurut Pembebanannya

1).Pajak Langsung, yaitu pajak yang langsung dibayar atau dipikul oleh wajib pajak yang bersangkutan dan pajak ini langsung dipungut pemerintah dari wajib pajak, tidak dapat dilimpahkan kepada orang lain.

2).Pajak Tidak Langsung, yaitu pajak yang dipungut kalua ada suatu peristiwa atau perbuatan tertentu, seperti penggerakan barang tidak bergerak, pembuatan akte, dan lain-lain dan pembayar pajak dapat melimpahkan beban pajaknya kepada pihak lain serta pajak ini tidak mempergunakan surat ketetapan pajak. Contoh: PPN dan PPnBM, Bea Materai.

c. Menurut Kewenangannya.

1).Pajak Pusat, yaitu pajak yang wewenang pemungutannya atau dikelola oleh Pemerintah Pusat dan hasilnya dipergunakan untuk membiayai pengeluaran rutin negara dan pembangunan (APBN). Contoh: PPh, PPN dan PPn BM, Bea Materai.

2).Pajak Daerah, yaitu pajak yang wewenang pemungutannya atau dikelola 
oleh Pemerintah Daerah (baik Pemerintah Propinsi maupun Pemerintah Kabupaten/Kota) dan hasilnya dipergunakan untuk membiayai pengeluaran rutin dan pembangunan daerah (APBD). Contoh: Pajak Hotel, Pajak Restoran, Pajak Reklame, Pajak Kendaraan Bermotor.

\section{Tata Cara Pemungutan Pajak}

Menurut Mardiasmo (2013:4) pemungutan pajak dapat dilakukan berdasarkan 3 stelsel:

a. Stelsel Nyata (riel stelsel)

Pengenaan pajak didasarkan pada objek (penghasilan yang nyata), sehingga pemungutannya baru dapat dilakukan pada akhir tahun pajak, yakni setelah penghasilan yang sesungguhnya di ketahui. Stelsel nyata mempunyai kelebihan atau kebaikan dan kekurangan. Kebaikan stelsel ini adalah pajak yang dikenakan lebih realistis. Sedangkan kelemahannya adalah pajak baru dapat dikenakan pada akhir periode (setelah penghasilan riil diketahui).

b. Stelsel Anggapan (fictieve stelsel)

Pengenaan pajak didasarkan pada suatu anggapan yang diatur oleh undangundang. Misalnya, penghasilan suatu tahun pajak sudah dapat ditetapkan besarnya pajak yang terhutang untuk tahun pajak berjalan. Kebaikan stelsel ini adalah pajak dapat dibayar selama tahun berjalan, tanpa harus menunggu akhir tahun. Sedangkan kelemahannya adalah pajak yang harus dibayar tidak berdasarkan pada keadaan yang sesungguhnya.

c. Stelsel Campuran

Stelsel ini merupakan kombinasi antara stelsel nyata dan stelsel anggapan. Pada awal tahun, besarnya pajak dihitung berdasarkan suatu anggapan kemudian pada akhir tahun besarnya pajak disesuaikan dengan keadaan yang sebenarnya. Bila besarnya pajak menurut kenyataan lebih besar dari pada pajak menurut anggapan, maka wajib pajak harus menambah sebaliknya, jika lebih kecil kelebihannya dapat diminta kembali.

\section{Asas Pemungutan Pajak}

Menurut Mardiasmo (2013:6) asas pemungutan pajak adalah sebagai berikut:

a. Asas Domisili (asas tempat tinggal)

Negara berhak mengenakan pajak atas seluruh penghasilan yang berasal dari dalam maupun dari luar negeri. Asas ini berlaku untuk wajib pajak dalam negeri.

b. Asas Sumber

Negara berhak mengenakan pajak atas penghasilan yang bersumber di wilayahnya tanpa memperthatikan tempat tinggal wajib pajak.

c. Asas Kebangsaan

Pengenaan pajak dihubungkan dengan kebangsaan suatu negara.

\section{Sistem Pemungutan Pajak}

Menurut Mardiasmo (2013:7) sistem pemungutan pajak adalah sebagai berikut:

a. Official Assesment System

Adalah sistem pemungutan yang memberi wewenang kepada pemerintah (fiskus) untuk menentukan besarnya pajak yang terutang oleh wajib pajak. Ciri-cirinya:

1) Wewenang untuk menentukan besarnya pajak terutang ada pada fiskus.

2) Wajib pajak bersifat pasif. 
3) Utang pajak timbul setelah dikeluarkan surat ketetapan pajak oleh fiskus.

b. Self Assesment System

Adalah suatu sistem pemungutan pajak yang memberi wewenang kepada wajib pajak untuk menentukan sendiri besarnya pajak yang terutang.

Ciri-cirinya:

1) Wewenang unutuk menentukan besarnya pajak terhutang ada pada wajib pajak sendiri.

2) Wajib pajak aktif, mulai dari menghitung, menyetor dan melaporkan sendiri pajak yang terutang.

3) Fiskus tidak ikut campur dan hanya mengawasi.

c. With holding system

Adalah suatu sistem pemungutan pajak yang memeberi wewenang pada pihak ketiga (bukan fiskus dan bukan wajib pajak bersangkutan) untuk menentukan besarnya pajak yang terutang oleh wajib pajak.

\section{Subjek Pajak Penghasilan}

Menurut Siti Resmi (2014:75) Subjek Pajak Penghasilan adalah segala sesuatu yang mempunyai potensi untuk memperoleh penghasilan dan menjadi sasaran untuk dikenakan Pajak Penghasilan. Subjek Pajak akan dikenakan Pajak Penghasilan apabila menerima atau memperoleh penghasilan sesuai dengan peraturan perundang-undangan yang berlaku. Jika subjek pajak telah memenuhi kewajiban pajak secara objektif maupun subjektif maka disebut Wajib Pajak. Berdasarkan Pasal 2 ayat (1) UU No.36 Tahun 2008, Subjek Pajak di kelompokkan sebagai berikut:

a. Orang Pribadi dan warisan yangbelum terbagi.

b. Badan, termasuk di dalamnya Bentuk Usaha Tetap (BUT).

Subjek Pajak Penghasilan juga dikelompokkan menjadi Subjek Pajak dalam negeri dan Subjek Pajak luar negeri. Pengelompokkan tersebut diatur dalam Pasal 2 ayat (2) UU No.36 Tahun 2008 sebagai berikut:

1) Subjek Pajak dalam negeri adalah:

a) Orang pribadi yang bertempat tinggal di Indonesia, orang pribadi yang berada di Indonesia lebih dari 183 (serratus delapan puluh tiga) hari dalam jangka waktu 12 (dua belas) bulan, atau orang pribadi yang dalam satu tahun pajak berada di Indonesia dan mempunyai niat untuk bertempat tinggal di Indonesia.

b) Badan yang didirikan atau bertempat kedudukan di Indonesia, kecuali unit tertentu dari badan pemerintah.

c) Warisan yang belum terbagi sebagai kesatuan menggantikan yang berhak.

2) Subjek Pajak luar negeri, adalah:

a) Orang pribadi yang tidak bertempat tinggal di Indonesia, orang pribadi yang berada di Indonesia tidak lebih dari 183 (serratus delapan puluh tiga) hari dalam waktu 12 (dua belas) bulan, dan badan yang tidak didirikan dan tidak bertempat kedudukan di Indonesia, yang menjalankan usaha atau melakukan kegiatan melalui bentuk usaha tetap di Indonesia.

b) Orang pribadi yang tidak bertempat tinggal di Indonesia, orang pribadi yang berada di Indonesia tidak lebih dari 183 (seratus delapan puluh tiga) hari dalam jangka waktu 12 (dua belas) bulan, dan badan yang tidak didirikan dan tidak bertempat kedudukan di Indonesia, yang dapat menerima atau memperoleh penghasilan dari Indonesia tidak dari menjalankan usaha atau melakukan kegiatan melalui bentuk uasaha tetap di Indonesia. 


\section{Objek Pajak Penghasilan}

Menurut Siti Resmi (2014:80) Objek Pajak Penghasilan merupakan segala sesuatu (barang, jasa, atau kegiatan), yang dikenakan pajak. Objek Pajak Penghasilan adalah pengahasilan, yaitu setiap tambahan kemampuan ekonomis yang diterima atau diperoleh Wajib Pajak, baik yang berasal dari Indonesia maupun dari luar Indonesia, yang dapat dipakai untuk konsumsi atau untuk menambah kekayaan Wajib Pajak yang bersangkutan, dengan nama dan dalam bentuk apapun. Berdasarkan Pasal 4 ayat (1) UUNo.36 Tahun 2008, penghasilan yang termasuk Objek Pajak adalah:

a. penggantian atau imbalan berkenaan dengan pekerjaan atau jasa yang diterima atau diperoleh termasuk gaji, upah, tunjangan, honorarium, komisi, bonus, gratifikasi, uang pension, atau imbalan dalam bentuk lainnya, kecuali ditentukan lain dalam undang-undang;

b. hadiah dari undian atau pekerjaan atau kegiatan, dan penghargaan;

c. laba usaha;

d. keuntungan karena penjualan atau karena pengalihan harta;

e. penerimaan kembali pembayaran pajak yang telah dibebankan sebagai biaya dan pembayaran tambahan pengembalian pajak;

f. bunga termasuk premium, diskonto, dan imbalan karena jaminan pengembalian utang;

g. dividen, dengan nama dan dalam bentuk apapun, termasuk dividen dari perusahaan asuransi kepada pemegang polis, dan pembagian sisa hasil usaha koperasi;

h. royalti atau imbalan atas penggunaan hak;

i. sewa dan penghasilan lain sehubungan dengan penggunaan harta;

j. penerimaan atau perolehan pembayaran berkala;

k. keuntungan karena pembebasan utang;

I. keuntungan selisih kurs mata uang asing;

m. selisih lebih karena penilaian kembali aktiva;

n. premi asuransi;

o. iuran yang diterima atau diperoleh perkumpulan dari anggota yang terdiri dari Wajib Pajak yang menjalankan usaha atau pekerjaan bebas;

p. tambahan kekayaan neto yang berasal dari penghasilan yang belum dikenakan pajak;

q. penghasilan dari usaha berbasis syariah;

r. imbalan bunga sebagaimana dimaksud dalam Undang-undang yang mengatur mengenai ketentuan umum dan tata cara perpajakan dan surplus Bank Indonesia.

\section{Wajib Pajak}

Pengertian Wajib Pajak berdasarkan Undang-undang Nomor 16 Tahun 2009 tentang ketentuan umum dan tata cara perpajakan adalah: "Wajib Pajak adalah orang pribadi atau badan, meliputi pembayar pajak, pemotong pajak dan pemungut pajak, yang mempunyai hak dan kewajiban perpajakan sesuai dengan ketentuan peraturan perundang-undangan. Wajib pajak bisa berupa wajib pajak orang pribadi atau wajib pajak badan.

a. Wajib pajak orang pribadi 
Wajib pajak orang pribadi adalah setiap orang pribadi yang memiliki penghasilan di atas penghasilan tidak kena pajak. Di Indonesia, setiap orang wajib mendaftarkan diri dan mempunyai nomor pokok wajib pajak (NPWP), kecuali ditentukan dalam undang-undang.

b. Wajib pajak badan

Wajib pajak badan yang memiliki kewajiban perpajakan sebagai pembayar pajak, pemotong atau pemungut pajak, termasuk bentuk usaha tetap dan kontraktor atau operator di bidang usaha hulu minyak dan gas bumi.

Pengertian diatas menjelaskan bahwa setiap Wajib Pajak yang telah memenuhi persyaratan subjektif dan objektif sesuai dengan peraturan perundang-undangan perpajakan wajib mendaftarkan diri pada Kantor Direktorat Jenderal Pajak yang wilayah kerjanya meliputi tempat tinggal dan tempat kedudukan Wajib Pajak.

\section{Kepatuhan Wajib Pajak}

Menurut Komarawati dan Mukhtaruddin (2012:38) Kepatuhan Wajib Pajak merupakan kesadaran Wajib Pajak mengenai kewajibannya dalam hal perpajakan. Kesadaran adalah faktor yang berasal dari kemauan dan perubahan sikap Wajib Pajak dalam memenuhi kewajiban perpajakannya dan hak pajaknya. Kepatuhan material dapat meliputi juga kepatuhan formal, jadi Wajib Pajak orang pribadi adalah Wajib Pajak yang mengisi dengan jujur, baik dan benar SPT tersebut sesuai Undang-undang dan menyampaikannya ke kantor Pelayanan Pajak sebelum batas waktu yang di tentukan.

Wajib Pajak Patuh menurut Direktorat Jenderal Pajak Nomor. KEP-550/PJ/2000 yang telah diubah dengan Keputusan Dirjen Pajak Nomor KEP-213/PJ/2003. Keputusan Nomor KEP-550 merupakan tindak lajut dari Keputusan Mentrti Keuangan Nomor 554/KMK.04/2000 tentang kriteria Wajib Pajak yang dapat diberikan pengembalian pendahuluan kelebihan pembayaran pajak yang telah juga diubah dengan Keputusan Menteri Keuangan Nomor 235/KMK.03/2003, adalah sebagai berikut:

1. Tepat waktu dalam menyampaikan SPT tahunan dalam dua tahun terakhir;

2. Dalam tahun terakhir penyampaian SPT masa yang terlambat tidak lebih dari tiga masa pajak untuk setiap jenis pajak dan tidak berturut-turut;

3. SPT masa yang terlambat dimaksud telah disampaikan tidak lewat dari batas waktu penyampaian SPT Masa-masa pajak berikutnya:

4. Tidak mempunyai tunggakan pajak untuk semua jenis pajak, kecuali tunggakan pajak yang telah memperoleh izin mengangsur atau menunda pembayaran pajak, tidak termasuk tunggakan pajak sehubungan dengan Surat Tagihan Pajak (STP) yang diterbitkan untuk dua masa pajak terakhir.

5. Tidak pernah dijatuhi hukuman karena melakukan tindak pidana di bidang perpajakan dalam jangka waktu sepuluh tahun terakhir, dan

6. Dalam hal laporan keuangan diaudit oleh Akuntan Publik atau BPKP, harus dengan pendapat wajar tanpa pengeculian atau dengan pendapat wajar dengan pengecualian sepanajang pengecualian tersebut tidak mempengaruhi laba rugi fiskal.

Kepatuhan dapat terwujud dengan penyuluhan, pelayanan, dan penegakkan hukum yang dapat berupa pemeriksaan, penyidikan, dan penagihan dengan menempatkan Wajib Pajak sebagai subjek yang dihargai hak-hak dan kewajibannya. 
Tingkat kepatuhan Wajib Pajak yang dimaksdu dalam hal ini adalah kepatuhan Wajib Pajak efektif dalam pemenuhan kewajiban perpajakan.

Kadang Wajib Pajak memang sengaja menghindari kewajiban perpajakannya dengan tidak mendaftarkan SPT kepada KPP bahkan masih banyak Wajib Pajak yang melalaikan pajaknya dan Wajib Pajak yang memberikan ketidakjelasan alamat pada KPP sehingga SPT yang di kirimkan tidak diterima oleh Wajib Pajak yang bersangkutan. Wajib Pajak patuh menurut Keputusan Dirjen Pajak Nomor KEP550/PJ/2000 adalah Wajib Pajak yang telah ditetapkan oleh Direktorat Jenderal Pajak sebagai Wajib Pajak yang memenuhi kriteria tertentu sebagaimana dimaksud dalam Keputusan Menteri Keuangan Nomor 235/KMK.03/2013 Tentang kriteria Wajib Pajak yang dapat diberikan pengambilan pendahuluan kelebihan pembayaran pajak.

Jadi bisa disimpulkan bahwa kepatuhan Wajib Pajak adalah suatu keadaan dimana Wajib Pajak dalam memenuhi kewajiabn perpajakan dan melaksanakan hak perpajakannya sesuai dengan peraturan yang berlaku tanpa perlu diadakan pemeriksaan, investigasi seksama atupun ancaman dan penerapan saksi hukum maupun administrasi.

\section{Surat Pemberitahuan Tahunan (SPT)}

Menurut Diana (2013:190) Surat Pemberitahuan Tahunan (SPT) adalah surat yang oleh Wajib Pajak digunakan untuk melaporkan perhitungan dan pembayaran pajak, objek pajak, atau bukan objek pajak atau harta dan kewajiban menurut ketentuan peraturan perundang-undangan perpajakan.

\section{Fungsi Surat Pemberitahuan (SPT)}

Menurut Diana (2013:193) ada beberapa fungsi Surat Pemberitahuan yaitu:

a. Bagi Wajib Pajak

Fungsi SPT adalah sebagai sarana untuk melaporkan dan mempertanggung jawabkan perhitungan jumlah pajak yang sebenarnya terutang dan untuk melaporkan tentang:

1) Pembayaran atau pelunasan pajak yang telah dilaksanakan sendiri dan atau melalui pemotongan atau pemungutan pihak lain dalam 1 (satu) Tahun Pajak atau Bagian Tahun Pajak.

2) Penghasilan yang merupakan objek pajak dana tau bukan objek pajak.

3) Harta dan kewajiban.

4) Pembayaran dari pemotong atau pemungut tentang pemotongan atau pemungutan pajak orang pribadi atau badan lain dalam 1 (satu) Masa Pajak yang ditentukan peraturan perundang-undangan perpajakan yang berlaku.

b. Bagi Pengusaha Kena Pajak (PKP)

Fungsi SPT adalah sebagai sarana untuk melaporkan dan mempertanggung jawabkan perhitungan jumlah Pajak Pertambahan Nilai dan Pajak Penjualan atas Barang Mewah yang sebenarnya terutang dan untuk melaporkan tentang:

1) Pengkreditan Pajak Masukan dan Pajak Keluaran.

2) Pembayaran atau pelunasan pajak yang telah dilaksanakan sendiri oleh Pengusaha Kena Pajak dan atau melalui pihak lain dalam satu Masa Pajak, yang ditentukan oleh ketentuan peraturan perundang-undangan pajak yang berlaku. 
c. Bagi Pemotong atau Pemungut Pajak

Fungsi SPT adalah sebagai sarana untuk melaporkan dan mempertanggung jawabkan pajak yang dipotong atau dipungut dan seterusnya.

\section{Batas Waktu Penyampaian SPT}

Menurut Diana (2013:199) adapun batas waktu penyampaian SPT adalah sebagai berikut:

a. SPT Masa, paling lama dua puluh hari setelah akhir Masa Pajak, kecuali untuk SPT Masa PPh Pasal 22, PPN dan PPnBM yang dipungut oleh Direktorat Jenderal Bea dan Cukai yaitu secara mingguan paling lama pada hari kerja terakhir minggu berikutnya, dan SPT Masa PPh Pasal 22, PPN dan PPnBM yang dipungut oleh Bendahara paling lama 14 hari setelah Masa Pajak berakhir.

b. SPT Tahunan Pajak Penghasilan Wajib Pajak orang pribadi, paling lama 3 (tiga) bulan setelah akhir Tahun Pajak, sedangkan untuk SPT Tahunan Pajak Penghasilan Wajib Pajak badan, paling lama 4 (empat) bulan setelah akhir Tahun Pajak.

\section{Sanksi Tidak atau Terlambat Menyampaikan SPT}

Menurut Diana (2013:204) SPT yang tidak disampaikan atau disampaikan tidak sesuai dengan batas waktu yang ditentukan, dikenakan sanksi administrasi berupa denda:

a. SPT Tahunan PPh orang pribadi Rp 100 ribu;

b. SPT Tahunan PPh badan Rp 1 juta;

c. SPT Masa PPN Rp 500 ribu;

d. SPT Masa Lainnya Rp 100 ribu.

Bagi Wajib Pajak yang alpa tidak menyampaikan SPT atau menyampaikan SPT tetapi isinya tidak benar atau tidak lengkap dan dapat merugikan negara yang dilakukan pertama kali tidak dikenai sanksi pidana tetapi dikenai sanksi administrasi berupa kenaikan sebesar $200 \%$ dari pajak kurang dibayar.

Sanksi pidana juga dikenakan terhadap setiap orang karena kealpaannya tidak menyampaikan SPT atau menyampaikan SPT tetapi isinya tidak benar atau tidak lengkap sehinnga dapat menimbulkan kerugian pada pendapatan negara dan perbuatan tersebut merupakan perbuatan setelah perbuatan pertama kali, didenda paling sedikit 1 (satu) kali jumlah pajak terutang yang tidak atau kurang dibayar dan paling banyak 2 (dua) kali jumlah pajak terutang yang tidak atau kurang dibayar, atau dipidana kurungan paling singkat 3 (tiga) bulan atau paling lama 1 (satu) tahun.

Setiap orang yang dengan sengaja tidak menyampaikan SPT atau menyampaikan SPT tetapi isinya tidak benar atau tidak lengkap dan dapat merugikan negara, sehingga dapat menimbulkan kerugian pendapatan negara dipidana dengan pidana penjara paling singkat 6 (enam) bulan dan paling lama 6 (enam) tahun dan denda paling sedikit 2 (dua) kali jumlah pajak terutang yang tidak atau kurang dibayar dan paling banyak 4 (empat) kali jumlah pajak terutang yang tidak atau kurang bayar.

\section{Nomor Pokok Wajib Pajak.}

Pengertian Nomor Pokok Wajib Pajak sebagaimana yang tertera dalam Undang-undang Nomor 28 Tahun 2007 tentang Ketentuan Umum dan Tata Cara 
Perpajakan Pasal 1 Ayat (6) adalah "Nomor Pokok Wajib Pajak merupakan nomor yang diberikan kepada wajib pajak sebagai identitas dan sarana dalam administrasi perpajakan dalam melaksanakan hak dan kewajiban perpajakannya." Selanjutnya dalam penjelasan UU KUP Pasal 2 Ayat (1) NPWP memiliki fungsi sebagai berikut:

a. Sebagai tanda pengenal diri atau identitas wajib pajak.

b. Untuk menjaga ketertiban dalam pembayaran pajak dan pengawasan administrasi perpajakan.

Wajib pajak yang memiliki NPWP adalah wajib pajak yang telah memenuhi persyaratan subjektif dan objektif, yang mendaftarkan dirinya pada Kantor Pelayanan Pajak setempat untuk mendapatkan NPWP. Apabila wajib pajak tersebut tidak mendaftarkan dirinya, maka akan diterbitkan NPWP secara jabatan oleh Kantor Pelayanan Pajak setempat, sesuai dengan ketentuan umum dan tata cara perpajakan dan undang-undang yang berlaku. NPWP dipergunakan ketika wajib pajak tersebut mengisi SPT pajak terhutangnya.

\section{Penerimaan Pajak.}

Penerimaan pajak adalah penghasilan yang diperoleh pemerintah yang bersumber dari pajak rakyat. Menurut Mardiasmo (2013:155) ada beberapa sumber penerimaan pajak sebagai berikut:

a. Pajak Penghasilan (PPh)

Menurut Undang-undang Nomor 36 Tahun 2008 mengatur pengenaan pajak penghasilan terhadap objek pajak berkenaan dengan penghasilan yang diterima atau diperolehnya dalam tahun pajak. Undang-undang PPh menganut asas materil artinya penentuan mengenai pajak yang terutang tidak tergantung kepada surat ketetapan pajak.

b. Pajak Pertambahan Nilai (PPn)

Berdasarkan Undang-undang yang mengatur mengenai Pajak Pertambahan Nilai (PPn) Dan Pajak Penjualan Atas Barang Mewah (PPn BM) adalah Undang-undang Nomor 8 Tahun 1987 tentang Pajak Pertambahan Nilai Barang dan Jasa dan Pajak Penjualan Atas Barang Mewah sebagaimana telah beberapa kali diubah terakhir dengan Undang-undang Nomor 42 Tahun 2009. Undang-undang ini disebut Undang-undang Pajak Pertambahan Nilai.

c. Bea Materai

Dasar hukum pengenaan Bea Materai adalah Undang-undang Nomor 13 Tahun 1985 atau disebut juga Undang-undang Bea Materai. Undang-undang ini berlaku sejak tanggal 1 Januari 1986. Selain itu untuk mengatur pelaksanaannya, telah dikeluarkan Peraturan Pemerintah Nomor 7 Tahun 1995 sebagaimana telah dirubah dengan peraturan pemerintah No 24 Tahun 2000 tentang Perubahan Tarif Bea Materai dan besarnya batas pengenaan harga nominal yang dikenakan Bea Materai. Dari Undang-undang tersebut pengertian Bea Materai adalah pajak atas dokumen.

d. Pajak Bumi Dan Bangunan

Berdasarkan Undang-undang No 12 Tahun 1985 mengenai Pajak bumi dan bangunan sebagaimana telah dirubah dengan Undang-undang No 12 Tahun 1994 bahwa Bumi adalah permukaan bumi dan tubuh bumi yang ada di bawahnya sedangkan bangunan adalah konsrtuksi teknik yang ditanam atau dilekatkan secara tetap pada tanah atau perairan. 
e. Bea Perolehan Hak atas Tanah dan Bangunan

Sesuai dengan pasal 33 ayat (3) Undang-undang dasar 1945, bumi, air, dan kekayaan alam yang terkandung didalamnya dikuasai oleh negara dan dipergunakan untk sebesar-besarnya kemakmuran rakyat. Tanah sebagai bagian dari bumi yang dikarunia tuhan yang maha esa, untuk memenuhi kebutuhan dasar dan lahan usaha. Sedangkan bangunan juga memberi manfaat ekonomi bagi pemiliknya.

Jadi bisa disimpulkan bahwa Penerimaan Pajak adalah penghasilan yang diperoleh dari pemerintah yang bersumber dari objek pajak seperti Pajak Penghasilan (PPh), Pajak Pertambahan Nilai (PPn), Bea Materai, Pajak Bumi dan Bangunan serta dari Bea Perolehan Hak Atas Tanah dan Bangunan, yang sesuai undang-undang.

\section{METODE PENELITIAN}

Menurut Sugiyono (2016:13) penelitian kuantitatif adalah metode penelitian yang berlandaskan pada filsafat positivisme, digunakan untuk meneliti pada populasi atau sampel tertentu, teknik pengambilan sampel pada umumnya dilakukan secara random, pengumpulan data menggunakan instrument penelitian, analisis data bersifat kuantitatif/statistic dengan tujuan untuk menguji hipotesis yang telah ditetapkan.

Dalam penelitian ini metode yang digunakan adalah metode kuantitatif dimana jenis data yang digunakan dalam penelitian ini berupa angka-angka dan dianalisa berdasarkan jumlah SPT tahunan Orang Pribadi yang menyampaikan dan jumlah penerimaan pajak orang pribadi yang terdaftar pada Kantor Pelayanan Pajak Pratama Palembang llir Timur tahun 2014-2018.

\section{Variabel Penelitian}

Menurut Sugiyono (2014:38) variable penelitian adalah sesuatu atribut atau sifat atau nilai dari orang, obyek atau kegiatan yang mempunyai variasi tertentu yang ditetapkan oleh peneliti untuk di pelajari.

Dalam penelitian ini penulis menggunakan dua variabel, yaitu: Kepatuhan Wajib Pajak Orang Pribadi dan Penerimaan Pajak.

\section{Definisi Operasional Variabel}

TABEL DEFINISI OPERASIONAL VARIABEL

\begin{tabular}{|c|c|c|}
\hline Variabel & Definisi & Indikator \\
\hline Kepatuhan & Kepatuhan Wajib Pajak Orang Pribadi & Jumlah Kepatuhan \\
\hline Wajib Pajak & adalah kesadaran Wajib Pajak mengenai & Wajib Pajak Orang \\
\hline Orang Pribadi & $\begin{array}{l}\text { kewajibannya dalam hal perpajakan. } \\
\text { Kesadaran adalah faktor yang berasal } \\
\text { dari kemauan dan perubahan sikap Wajib } \\
\text { Pajak dalam memenuhi kewajiban } \\
\text { perpajakannya dan hak pajaknya. } \\
\text { (Komarawati dan Mukhtaruddin: } 2012: 38 \text { ) }\end{array}$ & $\begin{array}{l}\text { Pribadi dalam } \\
\text { menyampaikan } \\
\text { SPT tahun 2014- } \\
2018\end{array}$ \\
\hline $\begin{array}{l}\text { Penerimaan } \\
\text { Pajak Orang } \\
\text { Pribadi }\end{array}$ & $\begin{array}{l}\text { Penerimaan Pajak adalah penghasilan } \\
\text { yang diperoleh pemerintah yang } \\
\text { bersumber dari pajak rakyat. } \\
\text { (Mardiasmo: } 2013: 155 \text { ) }\end{array}$ & $\begin{array}{l}\text { Jumlah } \\
\text { Penerimaan Pajak } \\
\text { Orang Pribadi } \\
\text { tahun 2014-2018 }\end{array}$ \\
\hline
\end{tabular}




\section{Populasi dan Sampel}

\section{Populasi}

Menurut Sujarweni (2014:65) populasi adalah keseluruhan jumlah yang terdiri atas obyek atau subyek yang mempunyai karakteristik dan kualitas tertentu yang ditetapkan oleh peneliti untuk diteliti dan kemudian ditarik kesimpulannya. Populasi dalam penelitian ini adalah seluruh wajib pajak orang pribadi yang terdaftar di Kantor Pelayanan Pajak Pratama Palembang llir Timur.

2. Sampel

Menurut Sujarweni (2014:65) sampel adalah bagian dari sejumlah karakteristik yang dimiliki oleh populasi yang digunakan untuk penelitian.

Sampel dalam penelitian ini adalah jumlah SPT tahunan Orang Pribadi yang menyampaikan dan jumlah penerimaan pajak Orang Pribadi yang terdaftar di KPP Pratama Palembang llir Timur tahun 2014-2018.

\section{Sumber Data}

Menurut Sugiyono (2014:46) sumber data yang digunakan dalam penelitian terdiri atas data primer dan data sekunder.

1. Data Primer adalah sumber data yang di peroleh secara langsung dari sumber aslinya (tidak melalui media perantara)

2. Data Sekunder adalah sumber yang di peroleh dari penelitian secara tidak langsung dari melalui media perantara (diperoleh dan dicatat pihak lain.

Sumber data yang digunakan dalam penelitian ini adalah data sekunder.

\section{Teknik Pengumpulan Data}

Berikut ini jenis-jenis teknik pengumpulan data menurut Sugiyono (2014:240) yaitu:

1. Studi Pustaka

Studi pustaka dilakukan untuk memperoleh landasan teoritis yang berhubungan dengan masalah yang diteliti. Dilakukan dengan membaca, menelaah, dan meneliti jurnal-jurnal, majalah, buku, dan literatur-literatur lainnya berhubungan erat dengan masalah yang diteliti.

2. Dokumentasi

Dokumentasi merupakan catatan peristiwa yang sudah berlalu. Dokumen bisa berbentuk tulisan, yang berupa catatan biografi, cerita, peraturan dan kebijakan.

Teknik pengumpulan data yang digunakan pada penelitian ini adalah dokumentasi.

\section{Teknik Analisis Data}

Menurut Sugiyono (2014:147) penelitian deskriptif adalah penelitian yang digunakan untuk menganalisa data dengan cara mendeskripsikan atau menggambarkan data yang telah terkumpul sebagaimana adanya tanpa bermaksud membuat kesimpulan yang berlaku untuk umum atau generalisasi.

Pengumpulan data menggunakan instrumen penelitian, analisis data deskriptif dengan tujuan untuk menggambarkan, mendeskripsikan serta menganalisis hasil olahan data terkait dengan kepatuhan wajib pajak terhadap penerimaan pajak.

Adapun pengukuran tingkat kepatuhan Wajib Pajak dalam penelitian ini yaitu perbandingan antara jumlah penyampaian SPT Wajib Pajak Orang Pribadi dengan 
jumlah Wajib Pajak Orang Pribadi yang terdaftar. Dalam Surat Direktur Jenderal Pajak Nomor SE-18/PJ.22/2006 terdapat tata cara perhitungan tingkat kepatuhan wajib pajak sebagai berikut:

Tingkat Kepatuhan (\%) =

Jumlah Penyampaian SPT

Jumlah Wajib Pajak Orang Pribadi Terdaftar Wajib SPT

Adapun pengukuran penerimaan pajak yaitu perbandingan antara realisasi penerimaan pajak dengan target penerimaan. Menurut John Hutagoal (2008:325) perhitungan rasio penerimaan pajak dapat dirumuskan sebagai berikut:

$$
\text { Penerimaan Pajak OP }(\%)=\frac{\text { Realisasi Penerimaan }}{\text { Target Penerimaan }}
$$

\section{HASIL PENELITIAN}

\section{Potensi Kepatuhan Wajib Pajak Orang Pribadi}

Penulis mengambil data yang dibutuhkan dalam penelitian ini adalah data yang diambil berdasarkan permasalahan. Data-data yang diperoleh dari Kantor Pelayanan Pajak Pratama Palembang Ilir Timur adalah sebagai berikut:

1. Jumlah Wajib Pajak Orang Pribadi yang terdaftar tahun (2014-2018)

2. Jumlah SPT Orang Pribadi yang menyampaikan tahun (2014-2018)

3. Realisasi penerimaan pajak tahun (2014-2018)

4. Target penerimaan pajak tahun (2014-2018)

5. Tugas-tugas pokok, subbagian dan lain-lain.

Berikut ini berdasarkan pada tabel Wajib Pajak orang pribadi yang terdaftar dan jumlah SPT tahunan yang disampaikan pada KPP Pratama Palembang Ilir Timur tahun 2014-2018 yaitu:

\section{TABEL WAJIB PAJAK ORANG PRIBADI TERDAFTAR DAN SPT YANG MENYAMPAIKAN PADA KPP PRATAMA PALEMBANG ILIR TIMUR TAHUN 2014-2018}

\begin{tabular}{|c|c|c|c|c|}
\hline No & Tahun & Jumlah WPOP & $\begin{array}{c}\text { Jumlah WPOP yang } \\
\text { Wajib Menyampaikan } \\
\text { SPT }\end{array}$ & $\begin{array}{c}\text { Jumlah OP yang } \\
\text { Menyampaikan } \\
\text { SPT Tahunan }\end{array}$ \\
\hline 1 & 2014 & 130.604 & 79.529 & 48.839 \\
\hline 2 & 2015 & 138.751 & 77.936 & 54.264 \\
\hline 3 & 2016 & 147.940 & 59.771 & 53.516 \\
\hline 4 & 2017 & 156.145 & 64.997 & 55.223 \\
\hline 5 & 2018 & 166.794 & 72.777 & 52.419 \\
\hline
\end{tabular}

Sumber: KPP Pratama Palembang Ilir Timur (2019)

Dari tabel diatas menunjukkan bahwa jumlah wajib pajak orang pribadi yang terdaftar pada KPP Pratama Palembang Ilir Timur mengalami peningkatan setiap tahunnya, namun tidak semua wajib pajak orang pribadi yang menyampaikan SPT. Pada tahun 2014 orang pribadi yang menyampaikan hanya 48.839, sedangkan yang wajib menyampaikan SPT adalah berjumlah 79.529. Pada tahun 2015 orang pribadi yang menyampaikan SPT hanya 54.264 , sedangkan yang wajib menyampaikan SPT berjumlah 77.936. Pada tahun 2016 orang pribadi yang menyampaikan SPT hanya 53.516, sedangkan yang wajib menyampaikan SPT berjumlah 59.771. Pada tahun 2017 orang pribadi yang menyampaikan SPT hanya 55.223, sedangkan yang wajib 
menyampaikan SPT berjumlah 64.997. Pada tahun 2018 orang pribadi yang menyampaikan SPT hanya 52.419, sedangkan yang wajib menyampaikan SPT berjumlah 72.777 .

\section{Analisis Kepatuhan Wajib Pajak Orang Pribadi}

Berikut ini adalah perhitungan persentase peningkatan atau penurunan Wajib Pajak Orang Pribadi yang Terdaftar pada KPP Pratama Palembang Ilir Timur.

TABEL PERSENTASE PENINGKATAN/PENURUNAN KEPATUHAN WAJIB PAJAK ORANG PRIBADI PADA KPP PRATAMA PALEMBANG ILIR TIMUR

TAHUN 2014-2018

\begin{tabular}{|c|l|c|c|c|}
\hline Tahun & $\begin{array}{l}\text { Jumlah Wajib } \\
\text { Pajak Orang } \\
\text { Pribadi } \\
\text { (a) }\end{array}$ & $\begin{array}{l}\text { Wajib Pajak Orang } \\
\text { Pribadi } \\
\text { Sebelumnya } \\
\text { (b) }\end{array}$ & $\begin{array}{l}\text { Peningkatan } \\
\text { atau Penurunan } \\
\text { (c) }\end{array}$ & $\begin{array}{l}\text { Persentase } \\
\text { Peningkatan } \\
\text { atau Penurunan } \\
\text { (c/b) }\end{array}$ \\
\hline 2014 & 130.604 & - & - & - \\
\hline 2015 & 138.751 & 130.604 & 8.147 & $6,23 \%$ \\
\hline 2016 & 147.940 & 138.751 & 9.189 & $6,62 \%$ \\
\hline 2017 & 156.145 & 147.940 & 8.205 & $5,54 \%$ \\
\hline 2018 & 166.794 & 156.145 & 10.649 & $6,81 \%$ \\
\hline
\end{tabular}

Sumber: KPP Pratama Palembang llir Timur, data di olah (2019)

Dari tabel di atas, dapat dijelaskan bahwa pada tahun 2014 jumlah Wajib Pajak Orang Pribadi sebesar 130.604 Wajib Pajak. Pada tahun 2015 Wajib Pajak Orang Pribadi lebih besar dari tahun sebelumnya dan meningkat sebesar 8.147 dengan persentase 6,23\%. Pada tahun 2016 jumlah Wajib Pajak Orang Pribadi sebesar 147.940 lebih besar dari tahun 2015 dan meningkat sebesar 9.189 dengan persentase 6,62\%. Pada tahun 2017 jumlah Wajib Pajak Orang Pribadi sebesar 156.145 lebih besar dari tahun 2016 dan mengalami penurunan Wajib Pajak Orang Pribadi sebesar 8.205 dengan persentase 5,54\%. Pada tahun 2018 jumlah Wajib Pajak Orang Pribadi sebesar 166.794 lebih besar dari Wajib Pajak Orang Pribadi tahun 2017 sebesar 156.145 dengan peningkatan Wajib Pajak Orang Pribadi sebesar 10.649 dengan persentase peningkatan 6,81\%.

Sedangkan untuk melihat perkembangan Wajib Pajak Orang Pribadi pada tabel persentase peningkatan/penurunan menyampaikan SPT tahunan Orang Pribadi pada KPP Pratama Palembang llir Timur yaitu:

\section{TABEL PERSENTASE PENINGKATAN/PENURUNAN MENYAMPAIKAN SPT TAHUNAN WAJIB PAJAK ORANG PRIBADI PADA KPP PRATAMA PALEMBANG ILIR TIMUR TAHUN 2014-2018}

\begin{tabular}{|c|c|c|c|c|}
\hline Tahun & $\begin{array}{l}\text { SPT Tahunan } \\
\text { (a) }\end{array}$ & $\begin{array}{l}\text { SPT tahun } \\
\text { sebelumnya } \\
\text { (b) }\end{array}$ & $\begin{array}{l}\text { Peningkatan } \\
\text { atau penurunan } \\
\text { (c) }\end{array}$ & $\begin{array}{l}\text { Persentase } \\
\text { peningkatan atau } \\
\text { penurunan (c/b) }\end{array}$ \\
\hline 2014 & 48.839 & - & - & - \\
\hline 2015 & 54.264 & 48.839 & 5.425 & $11,10 \%$ \\
\hline 2016 & 53.516 & 54.264 & 748 & $1,37 \%$ \\
\hline 2017 & 55.223 & 53.516 & 1.707 & $3,18 \%$ \\
\hline 2018 & 52.419 & 55.223 & 2.804 & $5,07 \%$ \\
\hline
\end{tabular}

Sumber: KPP Pratama Palembang Ilir Timur, data di olah (2019) 
Dari tabel di atas, dapat dijelaskan bahwa pada tahun 2014 SPT Tahunan pajak Orang Pribadi yang menyampaikan sebesar 48.839. Pada tahun 2015 SPT Tahunan pajak Orang Pribadi yang menyampaikan lebih besar dari tahun sebelumnya sebesar 54.264 dengan mengalami peningkatan sebesar 5.425 dengan persentase $11,10 \%$. Pada tahun 2016 SPT Tahunan Wajib Pajak Orang Pribadi yang menyampaikan sebesar 53.516 lebih kecil dari tahun sebelumnya sebesar 54.264 dengan mengalami penurunan sebesar 748 dengan persentase 1,37\%. Pada tahun 2017 SPT Tahunan Wajib Pajak Orang Pribadi yang menyampaikan sebesar 55.223 lebih besar dari tahun sebelumnya sebesar 53.516 dengan mengalami peningkatan sebesar 1.707 dengan persentase 3,18\%. Pada tahun 2018 SPT Tahunan Wajib Pajak Orang Pribadi yang menyampaikan sebesar 52.419 lebih kecil dari tahun sebelumnya sebesar 55.223 dengan mengalami penurunan sebesar 2.804 dengan persentase $5,07 \% \%$.

TABEL REALISASI DAN TARGET PENERIMAAN PAJAK ORANG PRIBADI TAHUN 2014-2018

\begin{tabular}{|c|c|c|c|}
\hline No & Tahun & $\begin{array}{c}\text { Target Penerimaan Pajak } \\
\text { Orang Pribadi (a) }\end{array}$ & $\begin{array}{c}\text { Realisasi Penerimaan } \\
\text { Pajak Orang Pribadi (b) }\end{array}$ \\
\hline 1 & 2014 & 23.595 .929 .998 & 23.574 .536 .607 \\
\hline 2 & 2015 & 21.785 .671 .003 & 56.131 .481 .474 \\
\hline 3 & 2016 & 102.578 .879 .191 & 23.773 .548 .146 \\
\hline 4 & 2017 & 135.533 .664 .000 & 29.580 .821 .485 \\
\hline 5 & 2018 & 139.430 .981 .000 & 43.450 .666 .060 \\
\hline
\end{tabular}

Sumber: KPP Pratama Palembang Ilir Timur (2019)

Pada tabel diatas menunjukkan bahwa pada tahun 2014 realisasi penerimaan pajak orang pribadi sebesar Rp.23.574.536.607 tidak melebihi target penerimaan sebesar Rp.23.595.929.998. Namun pada tahun 2015 realisasi penerimaan pajak orang pribadi melebihi target penerimaan sebesar Rp.21 785.671.003. Pada tahun 2016 realisasi penerimaan pajak orang pribadi sebesar Rp.23.773.548.146 tidak melebihi target penerimaan sebesar Rp.102.578.879.191. Pada tahun 2017 realisasi penerimaan pajak orang pribadi sebesar Rp.29.580.821.485 tidak melebihi target penerimaan sebesar Rp.135.533.664.000. Pada tahun 2018 realisasi penerimaan pajak orang pribadi sebesar Rp.43.450.666.060 tidak melebihi target penerimaan sebesar Rp.139.430.981.000.

Berikut ini adalah tabel perhitungan persentase Tingkat Kepatuhan Wajib Pajak Orang Pribadi pada KPP Pratama Palembang Ilir Timur dengan rumus:

$$
\text { Tingkat Kepatuhan (\%) }=\quad \frac{\text { Jumlah Penyampaian SPT }}{\text { Jumlah Wajib Pajak Orang Pribadi Terdaftar Wajib SPT }}
$$




\section{TABEL PERHITUNGAN PERSENTASE TINGKAT KEPATUHAN WAJIB PAJAK ORANG PRIBADI DI KPP PRATAMA PALEMBANG ILIR TIMUR \\ TAHUN 2014-2018}

\begin{tabular}{|c|c|c|c|c|}
\hline Tahun & $\begin{array}{c}\text { Jumlah WP } \\
\text { OP Terdaftar } \\
\text { Wajib SPT } \\
(\mathrm{a})\end{array}$ & $\begin{array}{c}\text { SPT Tahunan } \\
\text { OP yang } \\
\text { Mrnyampaikan } \\
(\mathrm{b})\end{array}$ & $\begin{array}{c}\text { Tingkat } \\
\text { Kepatuhan } \\
\% \\
(\mathrm{~b} / \mathrm{a} \times 100 \%)\end{array}$ & $\begin{array}{c}\text { Kepatuhan } \\
\text { WP OP } \\
(\mathrm{d})\end{array}$ \\
\hline 2014 & 79.529 & 48.839 & $61,41 \%$ & Kurang Patuh \\
\hline 2015 & 77.936 & 54.264 & $69,63 \%$ & Kurang Patuh \\
\hline 2016 & 59.771 & 53.516 & $89,54 \%$ & Cukup Patuh \\
\hline 2017 & 64.997 & 55.223 & $84,96 \%$ & Cukup Patuh \\
\hline 2018 & 72.777 & 52.419 & $72,03 \%$ & Kurang Patuh \\
\hline
\end{tabular}

\section{Sumber: Data Olahan 2019}

Berdasarkan tabel diatas dapat dilihat bahwa pada tahun 2014 tingkat kepatuhan Wajib Pajak Orang Pribadi kurang patuh yaitu mencapai 61,41\%. Pada tahun 2015 tingkat kepatuhan mengalami kenaikan 8,22\% yaitu dari tahun 2014 $61,41 \%$ menjadi $69,63 \%$ tetapi masih dalam kriteria kurang patuh karena hanya mencapai 69,63\%. Pada tahun 2016 tingkat kepatuhan Wajib Pajak Orang Pribadi mengalami kenaikan sebesar 19,91\% yaitu dari tahun 2015 sebesar 69,63\% menjadi $89,54 \%$ sehingga termasuk kriteria cukup patuh. Pada tahun 2017 tingkat kepatuhan Wajib Pajak Orang Pribadi mengalami penurunan sebesar $4,58 \%$ yaitu dari tahun 2016 sebesar 89,54\% menjadi 84,96\% termasuk kriteria cukup patuh. Pada tahun 2018 tingkat kepatuhan Wajib Pajak Orang Pribadi mengalami penurunan sebesar 12,93\% yaitu dari tahun 2017 84,96\% menjadi 72.03\% termasuk kriteria kurang patuh.

\section{Kriteria Kepatuhan Wajib Pajak}

\begin{tabular}{|c|c|}
\hline Rasio & Kepatuhan Wajib Pajak \\
\hline$>100$ & $>100$ Sangat Patuh \\
\hline $90-100$ & $90-100$ Patuh \\
\hline $80-90$ & $80-90$ Cukup Patuh \\
\hline $60-80$ & $60-80$ Kurang Patuh \\
\hline$<60$ & $<60$ Tidak Patuh \\
\hline
\end{tabular}

Sumber: KPP Pratama Palembang Ilir Timur 2019

\section{Analisis Penerimaan Pajak}

Berikut ini adalah tabel perhitungan persentase realisasi penerimaan Pajak Orang Pribadi yang terdaftar pada KPP Pratama Palembang llir Timur dengan rumus sebagai brikut:

$$
\text { Penerimaan Pajak OP }(\%)=\frac{\text { Realisasi Penerimaan }}{\text { Target Penerimaan }}
$$




\section{TABEL PERHITUNGAN PERSENTASE PENERIMAAN PAJAK ORANG PRIBADI PADA KPP PRATAMA PALEMBANG ILIR TIMUR TAHUN 2014-2018}

\begin{tabular}{|c|c|c|c|c|}
\hline No & Tahun & $\begin{array}{c}\text { Target } \\
\text { Penerimaan Pajak } \\
\text { Orang Pribadi } \\
(\mathrm{a})\end{array}$ & $\begin{array}{c}\text { Realisasi } \\
\text { Penerimaan Pajak } \\
\text { Orang Pribadi } \\
\text { (b) }\end{array}$ & $\begin{array}{c}\text { Penerimaan } \\
\text { Pajak Orang } \\
\text { Pribadi } \\
\text { (b/a x 100\%) }\end{array}$ \\
\hline 1 & 2014 & 23.595 .929 .998 & 23.574 .536 .607 & $99,90 \%$ \\
\hline 2 & 2015 & 21.785 .671 .003 & 56.131 .481 .474 & $257,65 \%$ \\
\hline 3 & 2016 & 102.578 .879 .191 & 23.773 .548 .146 & $23,17 \%$ \\
\hline 4 & 2017 & 135.533 .664 .000 & 29.580 .821 .485 & $21,87 \%$ \\
\hline 5 & 2018 & 139.430 .981 .000 & 43.450 .666 .060 & $31,16 \%$ \\
\hline
\end{tabular}

\section{Sumber: KPP Pratama Palembang Ilir Timur (2019)}

Berdasarkan tabel diatas dapat dilihat bahwa target penerimaan pada tahun 2014 sebesar Rp.23.595.929.998 hampir terealisasi dengan tingkat penerimaan pajak mencapai 99,90\% yaitu sebesar Rp.23.574.536.607. Pada tahun 2015 target penerimaan sebesar Rp.21.785.671.003 sudah terealisasi dengan baik karena tingkat penerimaan pajak mencapai 257,65\% yaitu sebesar Rp.56.131.481.474, namun pada tahun 2016 target penerimaan tidak terealisasi karena tingkat penerimaan pajak hanya mencapai $23,17 \%$ belum mencapai target yang seharusnya sebesar Rp.102.578.879.191, namun hanya diterima sebesar Rp.23.773.548.146. Pada tahun 2017 target penerimaan tidak terealisasi karena tingkat penerimaan pajak hanya $21,87 \%$ belum mencapai target sebesar Rp.135.533.664.000 dan yang diterima hanya sebesar Rp.29.580.821.485. Pada tahun 2018 target penerimaan juga tidak terealisasi karena tingkat penerimaan pajak hanya 31,16\% dan target yang ingin dicapai sebesar Rp.139.430.981.000 namun yang diterima hanya Rp.43.540.666.060.

\section{E. PEMBAHASAN}

Hasil analisis yang telah dilakukan antara kepatuhan wajib pajak orang pribadi dengan penerimaan pajak orang pribadi menunjukkan hasil bahwa Tingkat Kepatuhan Wajib Pajak Orang Pribadi yang tinggi tidak menjamin tingkat penerimaan pajak meningkat seperti yang kita lihat dari hasil perhitungan persentase antara tingkat perhitungan kepatuhan dengan penerimaan pajak pada tahun 2016 dan 2017 dengan tingkat kepatuhan yang tinggi tidak menjamin meningkatnya penerimaan pajak pada tahun tersebut karena tidak mencapai target penerimaan yang telah ditentukan, hal ini terjadi karena wajib pajak orang pribadi hanya menyampaikan SPT tahunannya saja tetapi tidak melakukan kewajiban mereka untuk membayar pajak terhutangnya sehingga bisa mengakibatkan penerimaan pajak tidak meningkat dan tidak mencapai target yang telah ditentukan.

Penelitian ini sejalan dengan penelitian yang dilakukan oleh Rina dan Mukhtaruddin (2012) dengan hasil yaitu menunjukkan tingkat kepatuhan wajib pajak orang pribadi pada kantor pelayanan pajak pratama lahat masih rendah/kurang baik.

Berdasarkan hasil penelitian di atas dapat diperoleh keterangan bahwa terdapat hal-hal yang menyebabkan rendahnya tingkat kepatuhan Wajib Pajak Orang Pribadi 
yang dapat mengakibatkan rendahnya penerimaan pajak pada KPP Pratama Palembang llir Timur.

Faktor-Faktor Yang Mempengaruhi Kepatuhan Wajib Pajak Orang Pribadi Terhadap Penerimaan Pajak di KPP Pratama Palembang Ilir Timur dari sisi Wajib Pajak. Kurangnya kesadaran wajib pajak dalam menyampaikan SPT tahunan. Penyebab kurangnya kesadaran wajib pajak juga terkait karena wajib pajak tidak tahu kewajiban yang harus mereka penuhi setelah memperoleh NPWP. Selain itu, wajib pajak juga kurang mengerti arti penting pajak sehingga wajib pajak malas untuk melakukan pembayaran pajak. Kurang inisiatif dari wajib pajak. Salah satu usaha KPP Pratama Palembang Ilir Timur untuk meningkatkan kepatuhan wajib pajak yaitu dengan mangadakan sosialisasi kepada wajib pajak, akan tetapi ajib di KPP Pratama Palembang llir Timur kurang inisiatif.

\section{F. KESIMPULAN DAN SARAN}

\section{1) Kesimpulan} berikut:

Berdasarkan hasil analisis yang dilakukan, penulis menarik kesimpulan sebagai

a) Dari kewajiban perpajakan wajib pajak orang pribadi terhadap penerimaan pajak belum sepenuhnya dilaksanakan dengan baik, hal ini dapat dilihat dari tingkat kepatuhan wajib pajak orang pribadi yang masih kurang dalam menyampaikan SPT Tahunan. Kepatuhan wajib pajak orang pribadi pada tahun 2014 sampai dengan 2015 kurang patuh yaitu dengan persentase 61,41\% $69,63 \%$, pada tahun 2016 sampai dengan 2017, cukup patuh yaitu dengan persentase 89,54\%,84,96\%, pada tahun 2018 kepatuhan wajib orang pribadi kembali kurang patuh karena hanya mencapai 72,03\%. Sedangkan berdasarkan target penerimaan pajak orang pribadi dapat disimpulkan bahwa KKP Pratama Palembang Ilir Timur belum mampu memenuhi atau mencapai target penerimaan pajak yang telah ditentukan hal ini dapat kita lihat pada tahun 2014-2018 meningkat namun tidak rasional karena pada tahun 2015 mengalami penurunan mencapai 7,67\% dari tahun 2016 sampai dengan 2018 mengalami kenaikan mencapai 370,85\%, 32,13\%, 2,87\%. Menurut realisasi penerimaan pajak orang pribadi dari tahun 2014-2018 hanya satu tahun yang mencapai target penerimaan yaitu tahun 2015 dengan persentase 257,65\%.

b) Berdasarkan faktor-faktor yang mempengaruhi Kepatuhan Wajib Pajak Orang Pribadi Terhadap Penerimaan Pajak pada Kantor Pelayanan Pajak Pratama Palembang Ilir Timur dari sisi wajib pajak yaitu kurangnya kesadaran wajib pajak dalam menyampaikan SPT tahunan, kurangnya inisiatif dari wajib pajak untuk membayar pajak.

c) Berdasarkan faktor-faktor yang mempengaruhi Kepatuhan Wajib Pajak Orang Pribadi Terhadap Penerimaan Pajak pada Kantor Pelayanan Pajak Pratama Palembang Ilir Timur dari sisi KPP Pratama Palembang Ilir Timur yaitu jaringan komputer, sosialisasi tidak tepat sasaran, Birokrasi yang panjang, lokasi pembayaran, sanksi kurang tegas.

\section{2) Saran}

Berdasarkan kesimpulan di atas, maka penulis memberikan saran sehubungan dengan penelitian ini adalah: 
a) Salah satu hambatan yang dihadapi oleh Kantor Pelayanan Pajak Pratama Palembang Ilir Timur dalam meningkatkan penerimaan pajak adalah rendahnya kesadaran dan kepatuhan wajib pajak dalam melaporkan dan menyampaikan SPT-nya, serta dalam membayar pajak. Untuk mengatasi hal tersebut KPP Pratama Palembang Ilir Timur dapat melakukan sosialisasi mengenai manfaat dan pentingnya membayar pajak bagi pemerintah dan masyarakat sendiri.

b) Dalam upaya meningkatkan penerimaan pajak KPP Pratama Palembang Ilir Timur dapat menerapkan sanksi tegas dan berat bagi wajib pajak yang tidak melunasi pajak terhutangnya atau tidak jujur dalam mengisi SPT-nya.

c) KPP Pratama Palembang llir Timur dapat memberikan penghargaan kepada wajib pajak yang patuh dalam menjalankan kewajiban perpajakannya. Hal ini dapat memeberikan pengaruh baik pada wajib pajak lain dan meningkatkan kesadaran masyarakat untuk membayar pajak guna meningkatkan penerimaan pajak.

\section{DAFTAR PUSTAKA}

Direktorat Jenderal Pajak, 2007, Panduan Hak dan Kewajiban Wajib Pajak. Jakarta (www.Pajak.go.id)

Direktorat Jenderal Pajak Nomor SE-18/PJ.22/2006, Tata Cara Perhitungan Key Performance Indicator Kepatuhan Wajib Pajak.

Hutagaol, John. 2008. Perpajakan: Isu isu Kontemporer, Yogyakarta: Graha Ilmu.

Komarawati, Dewi Rina dan Mukhtaruddin. 2012. Analisis Tingkat Kepatuhan Wajib Pajak Orang Pribadi Terhadap Tingkat Penerimaan Pajak Di Kabupaten Lahat. Jurnal infestasi Vol.8. No.1 Juni 2012. Hal 33-34.

Mardiasmo, 2013. Perpajakan. Edisi Revisi 2013. Andi. Yogyakarta.

Resmi, Siti. 2014. Perpajakan Teori dan Kasus. Jakarta: Salemba Empat

Republik Indonesia, 2009. Undang-Undang No.16 tahun 2009 tentang Perubahan Ke Empat Atas Undang-Undang Nomor 6 Tahun 1983 tentang Ketentuan Umum dan Tata Cara Perpajakan (UU KUP).

Sugiyono, 2014. Metode Penelitian Pendekatan Kuantitatif Kualitatif dan R\&D, Alfabeta, Bandung.

Sugiyono, 2016. Metode Penelitian Pendekatan Kuantitatif Kualitatif dan R\&D, Alfabeta, Bandung.

Sujarweni, V.Wiranata. 2014. Metode Penelitian Lengkap Praktis dan Mudah Dipahami. Pustaka Baru Press. Yogyakarta

Sari, Diana. 2013. Konsep Dasar Perpajakan. Cetakan Kesatu. PT Raja Grafindo Persada. 